\title{
ANALISIS PROSES KREATIF PRODUKSI FILM PADA KOMUNITAS FISABILILLAH PRODUCTION (FISPRO) KOTA MEDAN
}

\author{
Sri Wahyuni ${ }^{1}$ dan Triadi Sya'dian ${ }^{2}$ \\ Prodi Televisi dan Film \\ Fakultas Seni dan Desain Universitas Potensi Utama \\ Sriwahyuni2909@gmail.com, trisya'dian@gmail.com
}

\begin{abstract}
ABSTRAK
Penelitian ini bertujuan untuk menguraikan serta mendeskripsikan strategi kreatif produksi film pada komunitas Fisabilillah Production (Fispro). Fisabilillah Production merupakan komunitas film yang berada di Kota Medan merupakan sebuah komunitas perfilman yang berdomisili di Medan yang berdiri sejak tahun 2015. Komunitas perfilman ini bergerak di bidang dakwah yang bertujuan menciptakan karya dalam bentuk film yang dapat menginspirasi masyarakat serta dapat diterapkan dalam kehidupan sehari - hari. Metode yang digunakan pada penelitian ini yaitu penelitian deskriptif kualitatif. Hasil penelitian proses kreatif yang digunakan pada Komunitas Fispro yaitu pertama berdasarkan rancangan proses pra-produksi melalui ide / tema skenario, casting, reading dan rehearsal. Proses kreatif yang digunakan pada saat produksi dengan menekankan kepada miseen-scene yaitu : 1) gambar/adegan ;2) pergerakan pemain dan kamera ; 3) sinematografi ; 4) penataan cahaya ; 5) seting dan properti ; 6) penataan suara ; dan 7) editing. Sedangkan pada saat pasca produksi sendiri sutradara tidak menggunakan strategi-strategi khusus.
\end{abstract}

Kata Kunci : Proses Kreatif, Muhammad Fazruchi K, FISPRO

\section{ABSTRACT}

This Study aims ti discibe the creative strategy of film production in The Fisabilillah Production (Fispro) community. Fisabilillah Production is is a film community located in the city of Medan, a film community based in Medan which was founded in 2015. This film community is engaged in da'wah which aims to create works in the form of films that can inspire people and can be applied in everyday life. . The method used in this research is descriptive qualitative research. The results of the creative process research used in the Fispro Community are first based on the design of the pre-production process through scenario ideas / themes, casting, reading and rehearsals. The creative process used during production emphasizes mise-en-scene, namely: 1) image / scene; 2) the movement of players and cameras; 3) cinematography; 4) lighting arrangement; 5) settings and properties; 6) sound arrangement; and 7) editing. Meanwhile, in post-production, the director does not use specific strategies

Keywords : creative Process, Muhammad Fazruchi K, FISPRO

\section{PENDAHULUAN}

Film tercipta sebagai sebuah karya dari tenaga-tenaga kreatif profesional di bidangnya. Orang - orang yang terlibat langsung dalam suatu proses produksi film, masing - masing 
mempunyai keahlian yang dapat memberikan kontribusi tentang bagaimana menciptakan teknik visual yang menarik. Mereka adalah orang - orang inti dalam memproduksi film, diantaranya: Produser, Sutradara, penata Fotografi, Penulis Skenario, penata suara, penata artistik, prnyunting dan pemeran atau aktor Film memberikan pengalaman yang sangat mengasyikkan yang dapat membuat orang tertahan yang menjadikan mereka menontonnya lebih intens ketimbang medium lainnya.

Film merupakan sebuah bahasa kombinasi antara bahasa suara dan bahasa visual/gambar (pratista, 2008:3). Para sineas menawarkan solusi bagi para penonton agar nantinya film yang telah dibuat dapat diterima dengan baik bagi penonton baik melalui pengalaman mental yang dibangun oleh budaya yang dimilikinya. Film secara utuh dibangun oleh dua unsur yang saling berkesinambungan yaitu unsur naratif dan unsur sinematik. Kedua unsur tersebutlah yang menentukan film itu dipandang buruk (kurang memadai) atau baik bagi para penonton. Penonton yang kurang memahami maksud dan tujuan sebuah film akan menganggap film tersebut tidak bagus. Meskipun demikian, film adalah salah satu media massa yang sangat popular dan modern, film juga merupakan pernyataan budaya yang didalamnya adanya komunikasi yang akan disampaikan bagi si pembuat film kepada penontonnya di seluruh dunia (Heidir, 1991:1). Oleh karena itu, produksi film terus menunjukkan kebangkitannya hingga saat ini. Hal ini terlihat dari meningkatnya jumlah film Indonesia seiring dengan perkembangan bioskop Indonesia sekitar tahun 2012 hingga 2016. Akan tetapi, pada tahun 2017 jumlah film yang beredar mulai berkurang dibandingkan tahun 2016 walaupun tidak terlalu signifikan. Namun demikian, hal tersebut masih dianggap positif jika dibagi dengan jumlah penonton yang ada. Pada tahun 2017 jumlah film yang tersebar berdurasi panjang sebanyak 121 (60 menit) 5 diantaranya dokumenter sedangkan 116 film fiksi. (sumber : http://filmindonesia.or.id/article/kaleidoskop-2017-mengukur-detak-jantung-industri-filmindonesia\#.XXdQXvAzbhk diakses pada tanggal 10 April 2019 pukul 14:42 Wib).

Peningkatan dalam produksi film bukan hanya pada film-film layar lebar yang diproduksi oleh rumah produksi terkenal, melainkan kepada komunitas-komunitas di Indonesia yang ikut meramaikan Industri perfilman. Salah satunya, Komunitas film Medan yaitu Fisabilillah Production (FISPRO) merupakan sebuah komunitas perfilman yang berdomisili di Medan. Fispro berdiri sejak 2015 hingga sekarang. Komunitas perfilman ini bergerak di bidang dakwah yang bertujuan menciptakan karya dalam bentuk film yang dapat menginspirasi masyarakat serta dapat diterapkan dalam kehidupan sehari - hari. Fisabilillah Production menjadi komunitas yang mewadahi pemuda - pemudi yang ingin berkarya atau menjadi filmmaker religi untuk pengaplikasian cerita positif dan mendidik secara religi dan umum.

Muhammad Fazruchi K merupakan ketua dari komunitas Fisabilillah Production. Komunitas ini terbentuk karena adanya persamaan hobi di bidang filmmaker dengan beberapa teman - temannya. Dari hobi tersebut, muncul ide untuk membuat film pendek. Komunitas Fisabilillah Production beranggota para pelajar ataupun mahasiswa dari berbagai perguruan tinggi yang ada di Sumatera Utara maupun dari luar Sumatera Utara. Walupun berasal dari berbagai disiplin ilmu, mereka tetap memiliki visi dan misi yang sama, yaitu berdakwah melalui karya seni film pendek khususnya di kalangan remaja.Sekretariat Fispro berlokasi di jalan Garu I, Amplas, Medan kota.

Seiring berjalannya waktu, Fispro semakin berkembang dan berhasil menarik banyak penggemar. Pada tanggal 2 desember 2016, Fispro berhasil meraih sukses gelar juara 
$\begin{array}{lllll}\text { pertama } & \text { pada } & \text { festival } & \text { Film } & \text { Bandung }\end{array}$ (http://www.medanbisnisdaily.com/news/read/2016/12/07/272194/fisabilillah-productionluncurkan-film-baru/: diakses pada 28 februari 2018). Judul film yang diperlombakan Fispro pada festival Islamic Bandung tersebut adalah "Lenyap Dalam Sunyi”. Sebelumnya Film ini juga masuk menjadi nominasi film terpilih pada Indonesia Short Film Festival 2016 (ISFF). Berikut ini merupakan beberapa screenshoot film yang telah dii produksi oleh Fipro :

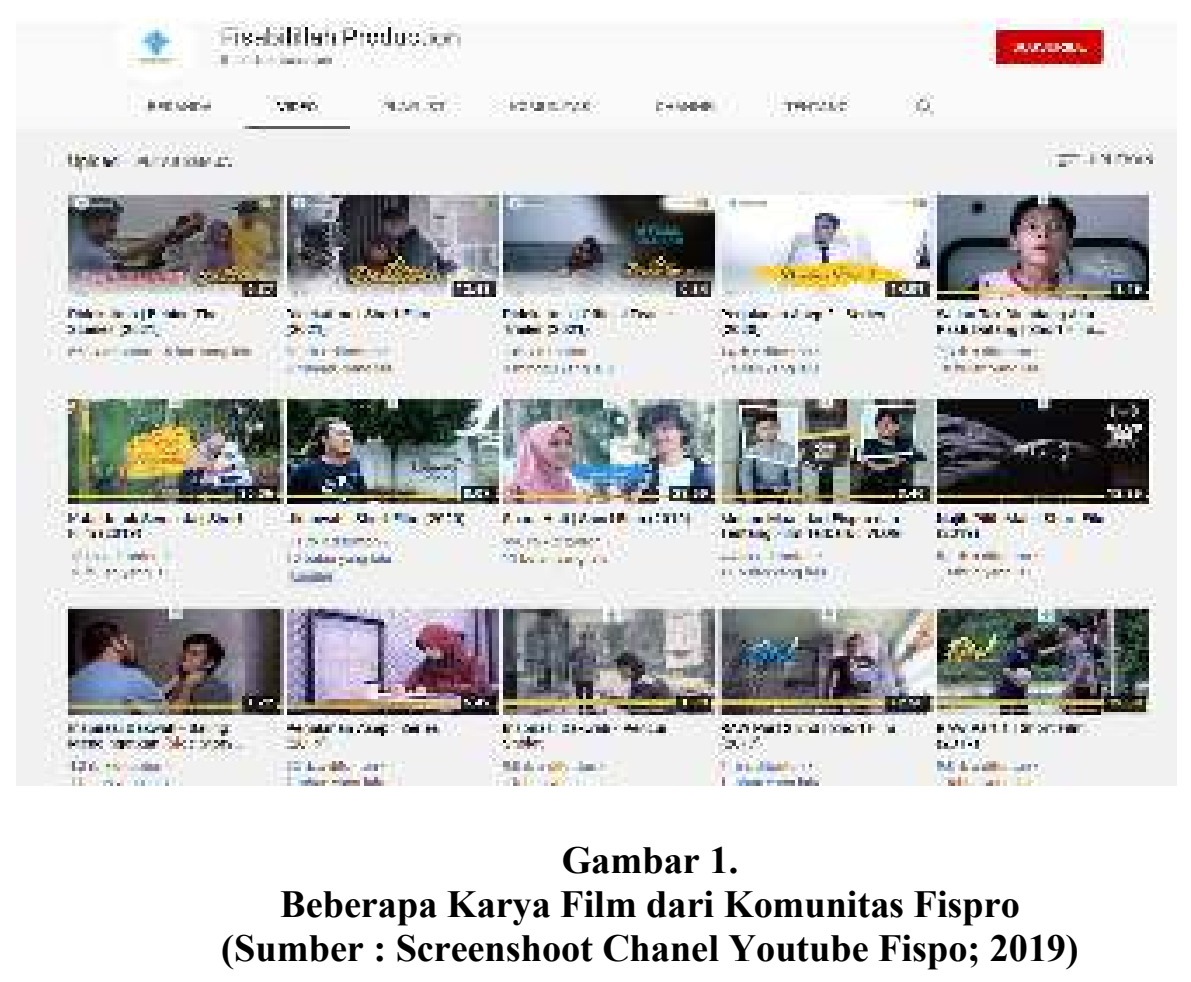

Berdasarkan uraian tersebut, Penelitian berjudul "Analisis Kreatif Produksi Film Pada Komunitas Film Fisabilillah Production (Fispro) Medan" menarik untuk dikaji khususnya kepada pemilihan tema-tema yang tidak lepas dari penyebaran dakwah dengan menggunakan medium film, yang mana dengan adanya penyebaran dakwah ini menjadikan penonton semakin sering melihat serta mendengar dakwah. Tentunya hal ini tidak terlepas dari strategi kreatif yang digunakan oleh Fispro (Muhammad Fazruchi K sebagai sutradara) dalam pengemasan film yang berlatar dakwah tersebut sehingga film-film yang diproduksi dapat diterima di masyarakat.

Proses kreatif pada produksi film komunitas Fispro dikaji/analisis menggunakan metode penelitian kualitatif dan bersifat deskriptif. Metode penelitian kualitatif merupakan penelitian yang bermaksud untuk memahami fenomena mengenai suatu kejadian yang dialami oleh subjek seperti prilaku, persepsi, motivasi dan lain sebagainya (Meleong, 2014:3). Selain itu, penelitian ini juga menggunakan teori kreativitas dengan menganalisis sutradara sekaligus ketua dari Komunitas Fispro yaitu Muhammad Ruchi K dengan menggunakan 4 tahapan dalam pemikiran kreatif John Haefele (1991: 64), yaitu (1) Preparation (Persiapan); (2) Incubation (Pengeraman), (3) Insight (Pemahaman), (4)Verification (Pengujian). Tahapan-tahapan kreativitas tersebut digunakan sebagai pembedah langkah-langkah kerja yang dilakukan oleh Muhammad Ruchi K dalam menulis skenario yang meliputi ide, tema, setting cerita, hingga menjadi skenario secara utuh. 
Selanjutnya proses produksi (pengambilan gambar dilapangan) hingga proses pasca produksi (editing).

\section{STUDI LITERATUR}

Terdapat beberapa tulisan/penelitian terdahulu yang menjadi rujukan atau referensi serta pembanding dengan penelitian yang disajikan. Hal ini bermaksud agar tidak terjadi penjiplakan dalam menyajikan penelitian. Adapun beberapa tulisan tersebut adalah sebagai berikut:

Penelitian Muna Rif'atil Akhlaq dan Sri Wastiwi Setiawati (2018) yang berjudul "Strategi Kreatif BW Purba Negara dalam Casting dan Directing Tokoh Mbah Sri pada Film Ziarah" yang diterbitkan dalam jurnal Capture Vol. 10 No. 1 Desember 2018. Penelitian ini menjelaskan mengenai proses kreatif BW Purba Negara selaku Sutradara, Penulis Naskah dan Produser. Penelitian ini menjelaskan bagaimana sutradara dapat memanipulasi keterbatasan dan kekurangan Mbah Ponco selaku Tokoh utama dalam Film Ziarah yang berperan sebagai Mbah Sri melalui strategi dalam casting dan directing. Casting yang dilakukan oleh BW Purba Negara dengan menggunakan cara mencari satu persatu nenek-nenek yang berusia 90-an tahun, masih memiliki kondisi fisik yang kuat dan mau diajak bermain film serta sesuai dengan karakter 3D tokoh Mbah Sri. Selain itu, Sutradara menggunakan pertimbangan kedekatan tokoh/pemeran dengan pengalaman hidupnya karena berkaitan dengan cerita di dalam film yang hendak di produksi bukan aktingnya. Adapun strategi kreatif yang digunakan sutradara BW Purba Negara yaitu : (1) BW Purba Negara membacakan naskah secara berulang-ulang hingga Mbah Ponco memahami isi naskah tersebut karena Mbah Ponco tidak dapat membaca; (2) BW Purba Negara melakukan revisi naskah setelah mendalami potensi mbah Ponco melalui ingatannya mengenai Agresi Militer II khususnya apa yang dialami oleh Mbah Ponco pada saat Perang; (3) BW Purba Negara memberikan latihan kepada Mbah Ponco untuk percaya diri di depan kamera melalui sesi pemotretan dengan menggunakan kostum, properti, dan gaya yang biasa digunakan. Hal ini dilakukan untuk melatih Mbah Ponco tampil didepan kamera karena Mbah Ponco bukan berasal dari artis profesional; (4) Usia Mbah Ponco yang sudah tua tidak mampu menghafal dialog panjang. BW Purba Negara menerapkan strategi mem-beo-kan atau menirukan dialog yang ada pada saat pengambilan gambar sehingga Mbah Ponco dapat menirukan apa yang disebutkan asisten sutradara; (5) Mbah Ponco diberikan doktrin mengenai karakter Prawiro secara eksplosif oleh sutradara dan asisten sutradara; (6) Menggunakan analogi Mbah Ponco sendiri dengan menggunakan bahasa-bahasa yang mudah dipahami oleh Mbah Ponco. Tulisan ini memiliki kesamaan dengan penelitian penulis yaitu menganalisis strategi kreatif yang digunakan oleh sutradara dalam menciptakan filmnya. Namun, meskipun demikian terdapat perbedaan pada objek yang dibahas dengan sutradara yang berbeda pula sehingga penelitian ini akan mengahasilkan hal yang berbeda pula.

Selanjutnya tulisan Widhi Nugroho, Titus Soeponi Adji dan Sri Wastiwi Setiawati yang berjudul "Proses Kreatif Eddie Cahyono dalam Penciptaan Film Siti" yang diterbitkan pada jurnal Capture Vol 8 No. 2 tahum 2017. Penelitian ini menganalisis mengenai proses kreatif dari Eddie Cahyono sebagai sutradara sekaligus penulis skenario pada film Siti. Penelitian ini menjelaskan bahwa ide awal skenario Siti berawal ketika Eddie membaca sebuah berita tentang penutuoan sebuah tempat karaoke di Pantai Parangtritis. Ide tersebut kemudian dikuatkan dengan berita meninggalnya seorang LC 
yang masih berusia delapan belas tahun karena menderita penyakit lever akibat dari minum-minuman keras. Peristiwa tersebut merupakan sebuah kekuatan Eddie ketika membaca lingkungan dengan menangkap peristiwa yang ada di sekitarnya. Strategi kreatif dalam menciptakan nasah (skenario cerita) dengan menggunakan repitisi dari lokasi (set dan tokoh. Kemudian konflik dalam cerita diberikan secara perlahan dengan urutan waktu satu hari. Selanjutnya proses kreatif dilakukan dari perwujudan mise-en-scene pada film Siti yang merupakan hasil terjemahan ide-ide kreatif sutradara karena keterbatasannya biaya yang dialokasikan untuk produksi film Siti. Proses produksi dilakukan dengan banyak memanfaatkan set lokasi yang direpetisi, pengambilan gambar secara long take hingga menggunakan pencahayaan natural (menggunakan cahaya matahari). Hal tersebut bertujuan demi dapat mengurangi atau memangkas biaya operasional serta meminimalisir penggunaan peralatan cahaya pada saat produksi. Selanjutnya Eddie juga melakukan latihan pola pengadeganan (blocking) pemain dilakukan secara detail dan mendalam, hal ini dilakukan karena di praproduksi Eddie telah menghitung dengan sangat cermat jumlah shot yang akan diperolah. Proses kreatif yang dilakukan oleh Eddie Cahyono dilakukan karena kurangnya budget produksi yang dimulai dari proses penulisan skenario hingga perwujudan skenario dalam mengolah mise-en-scene.

Selanjutnya tulisan Vedy Santoso yang berjudul "Kapital dan Strategi Garin Nugroho dalam Proses Produksi Film yang diterbitkan pada Journal of Urban Society's Arts Volume 2 Nomer 1 tahun 2017. Penelitian ini dilakukan untuk mengkaji strategi kreatif yang digunakan oleh Garin Nugroho selaku sineas yang mampu bertahan hingga saat ini baik di perfilman Nasional maupun Internasional. Pendekatan yang digunakan dalam penelitian ini yaitu strukturalisme genetik untuk menganalisis struktur sosial Garin Nugroho berdasarkan sosial-kultural Pierre Bourdieu. Pendekatan ini memiliki empat konsep utama yaitu habitus, arena, kapital dan strategi. Hasil yang diperoleh dari penelitian berdasarkan habitus Garin Nugroho yang menunjukkan dialektika internalisasi yang dapat menuntunnya lebib berani dengan menutup luka lama selanjutnya membuka luka baru pada masa transisi budaya global. Dengan demikian, Garin Nugroho memilih hubungan antara seni dan teknologi dalam memperjuangkan kreativitasnya. Untuk itu, strategi kreatif yang selalu diterapkan oleh Garin Nugroho dalam menghadapi era digital yaitu melalui kekonsistenannya kepada kecanggihan teknologi sebagai alat bantu untuk mewujudkan kreatifitas dalam memproduksi film. Meskipun dalam realitas masyarakat saat ini, modal ekonomi dan modal kultural cenderung menggantikan kekuasaan langsung terhadap individu. Dalam dunia seni, modal sosial dan modal simbolik lebih dihargai daripada bentuk modal yang lain. Hal ini kemudian menjadi strategi Garin Nugroho untuk mendapatkan sumber dana dalam memproduksi karya filmnya.

\section{PEMBAHASAN}

\section{III.1. Pra-Produksi}

Praproduksi merupakan tahapan kerja terpenting atau utama dalam setiap produksi film maupun televisi baik fiksi maupun dokumenter. Produksi film mampu berjalan lancar dan sukses karena berangkat dari persiapan produksi yang matang. Setiap permasalahan harus lebih dulu diselesaikan pada tahap praproduksi. Pada film yang sudah diciptakan oleh FISPRO ini, hal yang dilakukan pertama sekali yaitu riset untuk menggali berbagai informasi mengenai hal-hal yang ada di lapangan dan strategi-strategi kreatifnya serta dituangkan dalam bentuk treatment yang kemudian dievaluasi kembali untuk lebih dikonkretkan dan dikembangkan ke dalam bentuk skenario. Hasil riset menjadi titik 
berangkat pembentukan kerangka global mengenali arah dan tujuan penuturan, serta subjek-subjek yang akan menjadi tokoh (karakter) dalam film film.

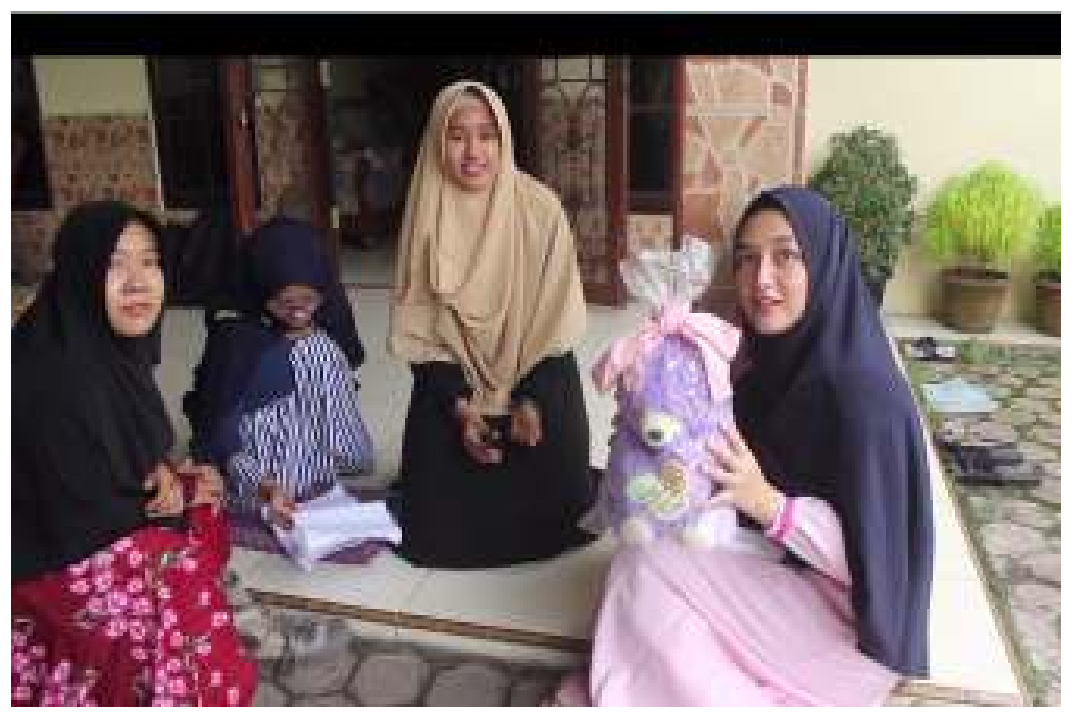

Gambar 2.

Kru dan Talent pada saat Pra Produksi

Peranan seorang penulisan naskah sangat penting, seperti yang disampaikan dalam buku Elizabeth Lutters yang berjudul "Kunci Sukses Menulis Skenario". Beberapa aspek yang mendukung kesuksesan dalam menulis skenario yaitu minat, bakat, motivasi, disiplin, penegtahuan dan pengalaman. Seorang penulis naskah tidak dapat hanya mengandalkan instingnya namun juga harus merujuk pada teori-teori yang sudah dikemukakan (Elizabeth Lutter, 2004:61).

Komunitas Fisabilillah Production berdiri pada tanggal 31 Agustus 2015 berfokus kepada film-film dakwah yang diketuai oleh M. Fazruchi bertempat tinggal di Medan. M. Fazruchi dan Tim pada dasarnya senang berkarya melalui sebuah film. Hal itu terbukti bahwa Komunitas Fisabilillah Production sudah menghasilkan kurang lebih 56 karya yang sudah di upload di chanel resmi Youtube Fisabilillah Production dan beberapa karya sudah memenangkan berbagai film festival. Tentunya Komunitas Fisabilillah Production memiliki strategi dalam memproduksi film-film tersebut sehingga film tersebut dapat diterima oleh masyarakat dan mampu bersaing pada film festival. Adapun startegi-strategi kreatif yang dilakukan oleh Komunitas Fisabilillah Production berada pada penekanan proses Praproduksi seperti sebagai berikut:

\section{A. Ide dan Tema Skenario}

Ide cerita merupakan gagasan sebuah cerita yang nantiya akan dituangkan menjadi sebuah cerita dalam skrenario (Elizabeth Lutters, 2004:46). Ide dalam sebuah film bisa didapat dari yang dilihat dan didengar atau bisa berasal dari kehidupan sehari-hari bahkan dapat berdasarkan suatu pemikiran imajinatif. Ide tidak muncul begitu saja, kadang dibutuhkan banyak membaca serta berkomunikasi dalam pergaulan, melihat lingkungan, juga berdiskusi dengan komunitas dan kelompok masyarakat yang memiliki aktivitas sosial dan budaya. Hal ini sejalan dengan apa yang disebutkan oleh Muhammad Fazruchi bahwa: 
"Dalam memikirkan atau menemukan sebuah ide banyak caranya, kalau dari Kami atau Saya pribadi itu lebih sering ke semacam khayalan, atau dari mimpi atau dari kisah oranglain yang paling sering menginspirasi. Saya itu kan paling sering buka instagram, kebetulan punya instagram jadi di instagram itu kan banyak cerita-cerita singkat, komik dan segala macam, beberapa bahkan dari komentar-komentar itu bisa jadi muncul ide. Idenya bisa berupa ntah dialog mereka dalam komentar-komentar atau ilustrasi gambar ditampilkan di instagram tersebut atau akun tersebut. Sehingga memunculkan ide baru gimana ya kalau di filmin.. gimana ya kalau difilmin gitu" (Wawancara Sutaradara Komunitas Fispro : 3 September 2019)

Dalam penuturan tersebut terlihat bahwa ide-ide yang muncul dalam penulisan/penggarapan sebuah skenario diambil dari hal-hal yang terdekat dengan sutradara seperti aktifitas, orang-orang sekeliling bahkan dari media sosial seperti instagram. Jadi setiap aktifitas yang dilakukan seperti ketika sedang jalan-jalan dan menemukan sesuatu yang baru, Sutradara sekaligus ketua dalam Komunitas Fisabillah Production langsung berfikiran untuk membuatnya ke dalam sebuah film yang nantinya mampu menginspirasi orang lain. Hal ini juga dikemukakan oleh Elizsbeth dalam bukunya menulis skenario bahwa ide dapat ditemukan dimana saja dan dalam keadaan apapun. Cerita dapat tercipta dari pengalaman pribadi atau bisa dari pengalaman orang lain. Aspek sosial pun sangat mempengaruhi terciptanya ide tersebut. Maka dari itu, sejatinya mencari ide tersebut sangatlah mudah karena ide bisa timbul dari mana saja (Elizabeth Lutter, 2004:47).

Melalui ide-ide tersebut Fisabilillah Production memiliki komitmen untuk membuat karya yang mudah diterima dengan masyarakat. Selain berkarya, Fisabilillah Production juga ingin hasil karyanya bermanfaat bagi orang lain sehingga muncul sebuah ide untuk menyajikan film-film dakwah kepada masyarakat dan hal ini menjadi ciri khas bagi Komunitas ini. Seluruh karya yang telah dibuat berlandaskan dakwah melalui ide-ide sederhana yang ditemukan dilingkungan dengan tujuan untuk memberikan ajakan-ajakan kebaikan melalui film-film yang dihasilkan.

\section{B. Casting, Reading dan Rehearsal \\ 1. Casting Pemain}

Seorang sutradara dibantu dengan asisten sutradara harus bertanggung jawab pada semua yang tampil pada layar. Ia melakukan kontrol terhadap adegan, pemain, aspek gambar dan editing pada sebuah film. Agar karya yang dihasilkan dapat maksimal Fisabilillah Production memiliki beberapa cara kreatif dalam merekrut para pemain sebagai berikut:

\section{Membuka Open Casting}

Open Casting ini dilakukan untuk mencari karakter yang sesuai dengan tokoh yang ada dikota Medan. Untuk permulaan dalam memproduksi sebuah film, cara ini sangat membantu mencari orang-orang yang memiliki bakat. Melalui proses ini sutradara dapat mudah memilah-milah tokoh-tokoh yang sesuai dengan karakter yang diperlukan.

2. Berdasarkan Kenalan (Door to Door)

Selain melalui cara Open Casting, sutradara juga menggunakan cara Door to Door. Jadi sutradara menghubungi kenalan-kenalan melalui teman yang sering terlibat dalam dunia acting sehingga dapat mempersingkat waktu pencarian pemain karena pemain sudah sering terjun dalam dunia acting dan sutradara juga lebih mudah mengarahkan pada saat proses latihan. 
Selain itu, Metode casting yang telah diterapkan oleh sutradara dilakukan dengan cara menganalisis kemampuan seorang talent dengan mengajak diskusi talent tersebut sehingga dapat terlihat kemampuan orang tersebut. Selama casting sutradara akan dibantu dengan asisten sutradara berdiskusi untuk menentukan talent yang cocok dengan karakter yang telah dicari.

\section{Reading}

Setelah mendapatkan pemain yang sesuai dengan karakter yang dicari, selanjutnya Sutradara melakukan proses reading. Reading merupakan pengarahan para pemain sesuai dengan skenario dan pencapaian kreatif sang sutradara. (Heru Effendy, 2009:55). Reading dilakukan bersama-sama membaca skenario sesuai porsi perannya masing-masing dan dibimbing oleh aisisten sutradara (Rikrik El Saptaria, 2006: 128). Dalam hal ini, Sutradara Fispro dan seluruh pemain yang terlibat melakukan proses reading. Proses reading ini dilakukan tidak hanya sekali, tetapi sutradara mengadakan pertemuan hingga beberapa kali hingga para pemainnya paham.

Pada proses reading ini sutradara menyesuaikan dengan formulasi penceritaan dalam naskah film yang dibuat. Beberapa naskah yang ada menitikberatkan pada kemampuan akting pemain sehingga tidak menutup kemungkinan naskah tersebut akan mengalami perubahan. Namun, ada juga naskah yang lebih menitikberatkan pada kemampuan miseenscene dan lainnya. Salah satu film yang menitikberatkan pada kemampuan akting yaitu film RAW Part I salah satu karya film Komunitas Fispro. Sehingga sutradra memiliki beberapa metode dalam melakukan reading seperti membacakan naskah/cerita, memberikan gambaran visual cerita seperti apa serta menirukan dialog pada naskah.

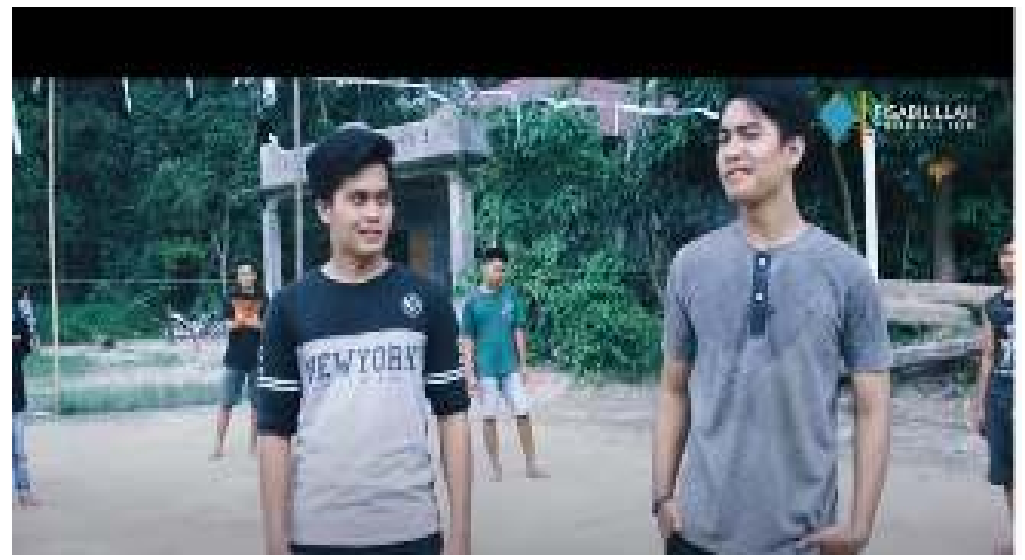

Gambar 3.

Screenshot Cuplikan Film RAW

(Sumber : Youtube Fispro, 2019)

\section{Rehearsal}

Rehearsal atau latihan dilakukan dengan cara mengatur tata gerak (blocking), mimik, dan bahasa tubuh disesuaikan dengan keinginan sutradara. Asisten sutradara membangun kepercayaan diri dan mood pemain, sehingga pada saat syuting dapat berjalan dengan lancar (Rikrik El Saptaria, 2006:128-129). Proses Rehearsal dilakukan oleh sutradara, asisten sutradara dan para pemain yang terlibat. Pada Komunitas Fispro sendiri proses Rehearsal dilakukan apabila terdapat adegan-adegan yang sulit dalam naskah. Jadi, sutradara dapat melakukan latihan-latihan yang dapat membantu para pemain misalnya menirukan adegan yang diinginkan oleh sutradara. 


\section{III.2. Produksi}

Proses produksi pada film-film yang telah diciptakan oleh Fispro merupakan hasil olahan dari proses pra produksi yang matang. Dimana semua pelaksanaan produksi merupakan hasil dari diskusi dan rapat produksi serta proses kreatif dari para seluruhkru tim produksi. Selain itu, Seorang sutradara harus bertanggung jawab pada semua yang ada yang tampil pada layar. Ia melakukan kontrol terhadap adegan, pemain, aspek gambar dan editing pada sebuah film. Kerja kreatif ini (kadang kala) bergantung pada budget produksi yang telah disediakan oleh produser. Artinya, seorang sutradara juga harus dapat mengukur potensi-potensi kerja kreatifnya dengan batasan-batasan yang telah disepakati bersama dengan produser film. Untuk itu, dibutuhkan sebuah strategi yang matang dalam usaha mewujudkan film yang sesuai dengan desain dan harapan yang telah dirancakan sebelumnya.

Sutradara selalu berupaya bagaimana mengelola strategi kreatif dengan buget yang juga terjangkau tentunya sehingga dalam hal ini strategi yang diperlukan yaitu : 1) gambar/adegan ; 2) pergerakan pemain dan kamera ; 3) sinematografi ; 4) penataan cahaya ; 5) seting dan properti ; 6) penataan suara ; dan 7) editing. Maka dari itu, strategi-strategi tersebut merujuk kepada mise-en-scene pada sebuah film. Pengambilan adegan tanpa putus dengan teknik kamera long take membutuhkan perhitungan yang matang pada setiap adegan yang dibuat. Tata letak pemain (blocking) dan pergerakan pemain harus diperhatikan sedemikan rupa sehingga keseluruhan adegan film ini dapat terekam secara natural. Nampak jelas, kerja kolaboratif antara sutradara dan penata kamera pada film ini sangat baik.

Fachruci merupakan sutradara yang sangat berperan cukup besar dalam menentukan tampilan film secara keseluruhan. Termasuk di dalamnya perlakukan terhadap tata cahaya pada film ini. Sebagai seorang penulis skenario dan sutradara, tidak jarang ia pun bertindak (kadang kala) sebagai produser dalam film ini. Hal ini dilakukan dengan pertimbangan bujet sehingga secara teknis ketika proses produksi pengambilan gambar sedapat mungkin dapat memangkas biaya. Bisa dikatan gaya "minimalis" diterapakan pada pencahayaan film ini. Lebih lanjut dalam sinematografi, framing dan aspek rasio mengambil peran penting pada penciptaan. Membatasi layar dengan bingkai/frame adalah cara seorang sutradara memandang dan mengambil sudut pandang artistik-estetik terhadap ruang lingkup peristiwa. Peristiwa-peristiwa itu kemudian ia hadirkan dalam bentuk adegan per adegan dalam sebuah film. Bagaimana cara kamera memandang adalah kunci keberhasilan informasi atau pesan yang disampaikan oleh sutradara kepada penonton dalam sebuah film. 


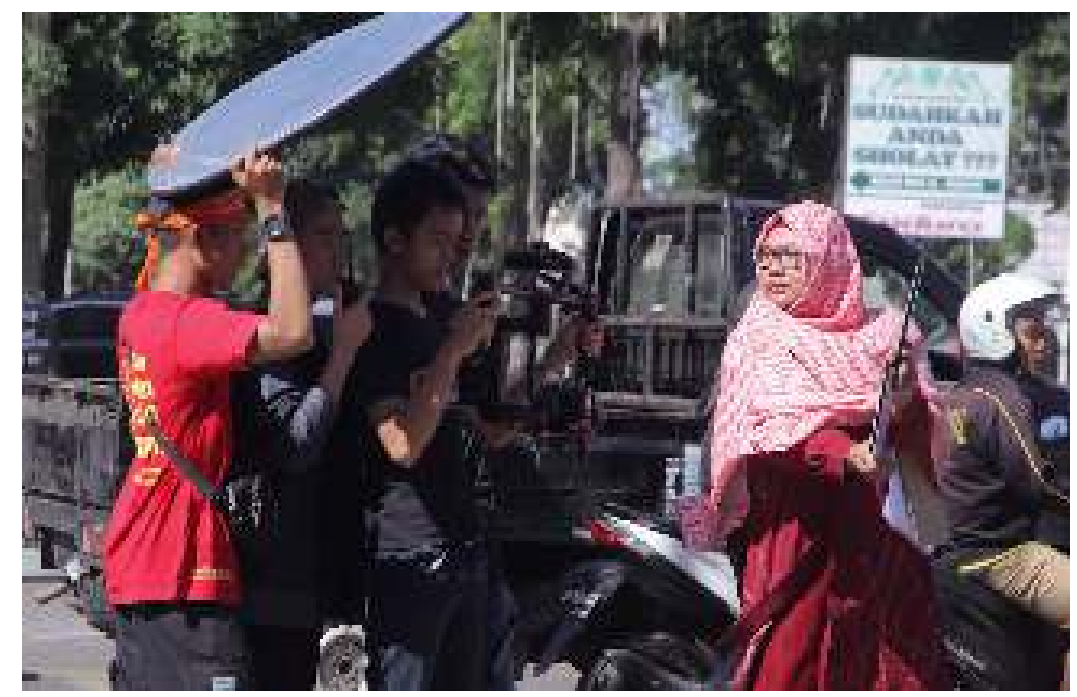

Gambar 3.

Proses Produksi Film pada Komunitas Fispro

(Sumber: Fispro, 2019)

\section{III.3. Pasca Produksi}

Setelah proses pra produksi dan produksi dilakukan, selanjutnya masuk ke proses pasca produksi. Editor memiliki peranan yang sangat penting dalam memproduksi sebuah film. Proses editing dilakukan berdasarkan editing script yang telah dibuat pada saat pra produksi. Editing Script sebagai panduan dalam melaksanakan proses editing. Hal ini, tentu juga menyesuaikan sinergi gambar dan suara sehingga penemotan narasi atau komentar yang berkaitan dengan gambar visual dapat sejalan. Proses editing yang dilakukan secara off-line dan on-line. Sutradara dan editor secara bersama-sama melihat seluruh hasil syuting (master shot) dengan memperhatikan secara selektif serta mencatat shot-shot yang penting. Selanjutnya shot-shot film dokumenter di edit secara on-line hingga menghasilkan film dokumenter yang utuh.

Selain itu, pada tahapan editing ini, pertimbangan pemangkasan frame dan aspek rasio merupakan gagasan sutradara yang kemudian dibicarakan dengan produser. Secara tidak langsung, makna yang muncul akibat dari pemangkasan frame dan aspek rasio ini memengaruhi kesan atau impresi penonton terhadap ruang yang dihadirkan melalui set ataupun lokasi yang dikenal dalam film ini. Impresi yang dimaksud adalah kesan terhadap ruang yang sempit, bersifat privasi dan cenderung pada aktivitas-aktivitas yang bersifat intim. Berikut merupakan hasil penjelasan dari sutaradara mengenai editing pada film-film yang telah disajikan :

"Cara-cara khusus apa ya.. enggak ada cara-cara khusus sih, Cuma biasanya ehh, saya biasanya kalau jadi sutradara gitu kan, sudah ada bayangan ketika baca naskah itu sudah ada bayangan nanti editingnya kayak apa apakah buat slow motion di editing atau nanti ini di editing kita buat paralel atau seperti ini seperti itu. Jadi, pada awal baca naskah itu biasanya sudah ketahuan, atau nanti pada saat editing biasanya ternyata lebih cocok seperti ini sambil berjalannya waktu" (Wawancara Sutaradara Komunitas Fispro : 3 September 2019)

Jika dilihat dari hasil wawancara diatas, maka sebenarnya pada tahapan editing ini tidak ada strategi-strategi khusus yang dilakukan sutradara / editor pada saat tahapan pasca 
produksi berlangsung. Semua tahapan yang dilakukan sesuai berjalan dengan kebutuhan yang dilihat diperlukan pada saat tahapan editing tersebut.

\section{KESIMPULAN}

Komunitas film Medan yaitu Fisabilillah Production (FISPRO) merupakan sebuah komunitas perfilman yang berdomisili di Medan. Fispro berdiri sejak 2015 hingga sekarang. Komunitas perfilman ini bergerak di bidang dakwah yang bertujuan menciptakan karya dalam bentuk film yang dapat menginspirasi masyarakat serta dapat diterapkan dalam kehidupan sehari - hari. Fisabilillah Production menjadi komunitas yang mewadahi pemuda - pemudi yang ingin berkarya atau menjadi filmmaker religi untuk pengaplikasian cerita positif dan mendidik secara religi dan umum. Komunitas Fisabilillah Production memiliki strategi dalam memproduksi film-film tersebut sehingga film tersebut dapat diterima oleh masyarakat dan mampu bersaing pada film festival.

Strategi yang dilakukan oleh Komunitas Fispro lebih mengedepankan pada proses pra produksi yaitu ide-ide yang muncul dalam penulisan/penggarapan sebuah skenario diambil dari hal-hal yang terdekat dengan sutradara seperti aktifitas, orang-orang sekeliling bahkan dari media sosial seperti instagram. Jadi setiap aktifitas yang dilakukan seperti ketika sedang jalan-jalan dan menemukan sesuatu yang baru, Sutradara sekaligus ketua dalam Komunitas Fisabillah Production langsung berfikiran untuk membuatnya ke dalam sebuah film yang nantinya mampu menginspirasi orang lain. Selain itu, strategi kreatif yang dilakukan Komunitas Fispro dilihat dari segi ide / tema skenario dan metode casting, reading dan rehearsal yang telah dilakukan.

Sedangkan untuk metode produksi dan pasca produksi pada Komunitas Fispro lebih menekankan kepada bagian mise-en-scene : 1) gambar/adegan ; 2) pergerakan pemain dan kamera ; 3) sinematografi ; 4) penataan cahaya ; 5) seting dan properti ; 6) penataan suara ; dan 7) editing. Maka dari itu, strategi-strategi tersebut merujuk kepada mise-en-scene pada sebuah film. Pengambilan adegan tanpa putus dengan teknik kamera long take membutuhkan perhitungan yang matang pada setiap adegan yang dibuat. Tata letak pemain (blocking) dan pergerakan pemain harus diperhatikan sedemikan rupa sehingga keseluruhan adegan film ini dapat terekam secara natural. Nampak jelas, kerja kolaboratif antara sutradara dan penata kamera pada film ini sangat baik. Pada tahapan editing ini tidak ada strategi-strategi khusus yang dilakukan sutradara / editor pada saat tahapan pasca produksi berlangsung. Semua tahapan yang dilakukan sesuai berjalan dengan kebutuhan yang dilihat diperlukan pada saat tahapan editing tersebut.

\section{DAFTAR PUSAKA}

[1] Gie, The Liang., Tehnik Befikir Kreatif, Yogyakarta: Sabda Persada, 2003

[2] Himawan Pratista. 2008. Memahami Film, Yogyakarta: Homerian Pustaka.

[3] Lutters, Elizabeth., Kunci Sukses Menulis Skenario,Jakarta: PT. Gramedia Widiasarana Indonesia, 2004.

[4] Moleong, Lexy J., Metodologi Penelitian Kualitatif, Bandung: Rosda karya, 2013 


\section{Jurnal :}

[1] Muna Rif'atil Akhlaq dan Sri Wastiwi Setiawati. 2018. Strategi Kreatif BW Purba Negara dalam Casting dan Directing Tokoh Mbah Sri pada Film Ziarah. Jurnal Capture Vol. 10 No. 1.

[2] Vedy Santoso. 2017. Kapital dan Strategi Garin Nugroho dalam Proses Produksi Film. Journal of Urban Society’s Art Vol. 04 No. 01.

[3] Wahyu Novianto. 2016. Konsep Kreativitas Garin Nugroho dan Keterlibatannya dalam Perfilman di Indonesia, Jurnal Acintya, Vol. 08 No. 02.

[4] Widhi Nugroho, Titus Soepono dan Sri Wastiwi S. 2017. Proses Kreatif Eddie Cahyono dalam Penciptaan Film Siti. Jurnal Capture Vol. 08 No. 02.

\section{Internet :}

[1] http://filmindonesia.or.id/article/kaleidoskop-2017-mengukur-detak-jantungindustri-film-indonesia\#.XXdQXvAzbhk diakses pada tanggal 10 April 2019 pukul $14: 42 \mathrm{Wib}$

[2] https://www.youtube.com/c/FisabilillahProduction diakses pada tanggal 10 April 2019 pukul $15.00 \mathrm{Wib}$ 